(C) 2016

\title{
Content of humus of black earth depending on fertilizer system in short-crop rotations
}

\author{
Ya. Tsvei, \\ doctor of agricultural science \\ S. Bondar, M. Kisilevska \\ Institute of Bioenergy Crops and Sugar Beet NAAS
}

The purpose. To study changes of quality indicators of humus in typical leached black earth depending on fertilizer system of sugar beet in different crop rotations. Methods. Long stationary experiment. Specimens of soil were taken from a stratum of $0-30 \mathrm{~cm}$ in the season of harvesting of sugar beet. The content of general humus in soil was determined using Tyurin's method, and group content of humus - using Kononova and Belchikova method. Results. Changes of group content of humus in typical leached black earth under the influence of application of organo-mineral fertilizer system for sugar beet depending on crop rotations are studied. Conclusions. The best quality indicators of humus are determined in grain-tilling crop rotation where the total humic and fulvic acids in organomineral fertilizer system makes $1,2 \%$ (HA - 0,78, FA - 0,42, linked with $\mathrm{R} 2 \mathrm{O} 3-18$, with $\mathrm{Ca}-82$ ).

Key words: typical leached black earth, humus, fulvic acids, humic acids, group content, crop rotation, fertilizer system.

Introduction. The long-term man-made burden on the agroecosystem affects changes in soil humus content and its quality, for the agronomical effect changes the natural course of humus formation, primarily of the humus substances which are complex organomineral compounds having different resistance to the man-made burden. $[1,7,15,16]$. Studies of recent years demonstrated that the level of Ukrainian soil provision with organic matter remains low, with an annual loss of humus estimated from 0.6 to $1 \mathrm{t} / \mathrm{ha}[3,5,6]$.

A research carried out at the Bila Tserkva Research \& Breeding Station on deep leached chernozem in ten-course crop rotations showed that in crop rotation without fertilization, the content of humic acids was $0.77 \%$, fulvic acids $0.41 \%$, while in row crop rotation $0.53 \%$ and $0.65 \%$, and in grain - row crop rotation $0.76 \%$ and $0.46 \%$, respectively. Against the background of the organomineral fertilization, these values were 0.89 and $0.45,0.58$ and $0.70,0.90$ and $0.50 \%$, respectively [6].

Fertilization program prescribing traditional and alternative sources of organic matter and ecologically balanced crop rotations may serve as the regulatory mechanism for stabilizing and improving stocks and qualitative composition of the soil organic matter $[8,9,11,1,18]$.

Chernozem of agricultural landscapes is predominantly of humate - fulvate and fulvate - humate type of humus formation; only on grassland humate type dominates, as the most typical of chernozem soils [4].

The purpose of the research was to study the changes in quality characteristics of humus in the deep leached chernozems as affected by fertilization program for sugar beet in different crop rotations.

Materials and methods. The research was carried out in the long-term stationary experiment (established in 1976) at the Bila Tserkva Research \& Breeding Station and involved various ten-course crop rotations.

The soil of the experimental field was typical deep leached chernozem of low-humus content, medium loamy with humus content in the $0-30 \mathrm{~cm}$ layer of 3.6-3.8\%, mobile phosphorus (by Chirikov) of 153-170 mg/kg and potassium (by Chirikov) of $6-78 \mathrm{mg} / \mathrm{kg}$ (by Chirikov), alkaline hydrolyzed nitrogen (by Cornfield) of $120-140 \mathrm{mg} / \mathrm{kg}$.

Registration area measured $100 \mathrm{~m}^{2}$ with three replications. Agronomic practices for the crops under experiment were typical for the zone of growing. The stationary experiment was reorganized in 2006 after three cycles of ten-course crop rotations into six-course crop rotations aiming at increasing crops productivity and preserving soil fertility.

Short crop rotations included the following set of crops: crop rotation: $33 \%$ fodder crops, $17 \%$ row crops, $50 \%$ grain crops (winter wheat - sugar beet - barley+clover - clover - winter wheat); row crop rotation: $17 \%$ fodder crops, $50 \%$ row crops, $33 \%$ grain crops (oat - winter wheat - barley - soya - 
sunflower); grain - row crop rotation: $17 \%$ fodder crops, $33 \%$ row crops, $50 \%$ grain crops (winter wheat - sugar beet - barley - rape - winter wheat).

Doses of fertilizer per 1 hectare of crop rotation were as following: mineral $-\mathrm{N}_{43} \mathrm{P}_{43} \mathrm{~K}_{43}$ and organic 8.3 t. Mineral fertilizers were introduced to all crops of crop rotation, except for oat and barley. Harvest residues of all crops were ploughed into the soil. The fertilization program for sugar beet and crop rotation is given in the table.

Soil samples were taken from a layer of $0-30 \mathrm{~cm}$ during the period of sugar beet harvesting. The content of total humus in the soil was determined by the Tiurin method and the group composition of humus by the Kononova and Belchikova method.

Research results. The research showed that the long-term man-made burden affects the content and quality composition of humus in the soil. Thus, in crop rotation in the control treatment (without fertilizers), the humus content in the topsoil was $3.14 \%$, which was at the level of grain-row crop rotation; at the same time in the crop rotation it was $3.10 \%$, which indicated a higher degree of humus mineralization

When applying organomineral fertilizers both in sugar beet and overall in the crop rotation, a general reproduction of the humus content was observed due to the peculiarity of the soil type, the structure of the crop rotation and the wetting zone. In the treatment where $50 \mathrm{t} /$ ha of manure $+\mathrm{N}_{100} \mathrm{P}_{100} \mathrm{~K}_{100}$ was applied for sugar beet and $8.3 \mathrm{t} / \mathrm{ha}+\mathrm{N}_{43} \mathrm{P}_{43} \mathrm{~K}_{43}$ applied overall for crop rotation, the humus content in crop rotation was $3.55 \%$ exceeding the value of the control treatment (without fertilizers) by $0.41 \%$. In the grain-row crop rotation, the increase in the humus content was $0.31 \%$ and in the row-crop rotation $0.24 \%$ that was less by $0.17 \%$, than in crop rotation due to the saturation of crop rotation with row crops to $50 \%$, while in the crop rotation the value was only $17 \%$.

Ploughing harvest residues (straw and corn stalks) into the soil contributed to maintaining the balance of humus in the soil. Thus, in the treatment of crop rotation with the ploughing straw into the soil + $\mathrm{N}_{100} \mathrm{P}_{100} \mathrm{~K}_{100}$, humus content in topsoil was $3.24 \%$ that was by $0.14 \%$ higher than in the control treatment without fertilizers, but at the same time lower by $0.21 \%$ if compared with the value in the treatment with $50 \mathrm{t} /$ ha of manure $+\mathrm{N}_{100} \mathrm{P}_{100} \mathrm{~K}_{100}$. This difference was due to the limited amount of dry matter and nitrogen entering the soil along with the manure.

The total carbon content when introducing $50 \mathrm{t} / \mathrm{ha}+\mathrm{N}_{100} \mathrm{P}_{100} \mathrm{~K}_{100}$ was the highest in crop rotation, specifically $2.06 \%$, while in grain-crop rotation the value was $2.0 \%$ and in the treatment without fertilizers $1.82 \%$ and $1.82 \%$, respectively.

In our research, application of organomineral fertilization program resulted in the proportion of humic acids in the humus in crop rotation at $0.74 \%$, while in row-crop rotation it was $0.60 \%$ and in the treatment without fertilizers $0.62 \%$ and $0.56 \%$, respectively. In grain-row crop rotation, where the percentage of row crops in the previous rotation was $50 \%$, and $33 \%$ at the time of the research, the content of humic acids was $0.78 \%$, while in the treatment without fertilizers it was $0.65 \%$. Consequently, an increase in the percentage of crop rotation for three rotations to $40 \%$ and a decrease for four and five rotations to $20 \%$ did not contribute to the increase in the proportion of humic acids.

In the treatment of crop rotation, where the straw and harvest residues of all the crops were ploughed into the soil, the content of humic acids was $0.68 \%$, which was inferior to the organomineral fertilizer system by $0.06 \%$.

In out experiment, the proportion of fulvic acids in humus in the control treatment reduced [10], while other researchers [12] reported its having been unchanged or even increased [13].

In the crop rotation treatment against the background of the organomineral fertilization, fulvic acids content was $0.44 \%$, in the grain-row crop rotation $0.42 \%$, in row crop rotation $0.51 \%$, while in the treatment without application of fertilizers it was $0.44,0.48$ and $0.44 \%$, respectively. By ploughing the straw into the soil and applying mineral fertilizers, the content of humic acids was $0.47 \%$. In the crop rotation, where the share of row crops in ten-course crop rotations was $60 \%$ for three rotations and $40 \%$ for grains without legume crops, when having shifted to six-course crop rotations with the share of legumes of $33 \%$, row crops of $50 \%$ and grain crops of $17 \%$, the process of fulvates formation did not reduced. Taking into account the previous studies [6], it can be stated that the long-term man-made burden for typical leached chernozem promotes an increase in fulvic acids content and at the same time a reduction in humic acids. This was true for both the treatments without fertilizers and with fertilizers. Under the effect of fertilization, the content of humic acids and the ratio between humic and fulvic acids varied. However, in general, humat-fulvate type of humus formation is characteristic of typical leached chernozem. 
For the chernozems under intensive agriculture, humate-fulvate humus formation is characteristic, and for the podzol and regraded chernozems fulvate-humate type of soil formation.

The ratio between humic and fulvic acids due to the application of organomineral fertilization practice was in crop rotation 1.69, in row-crop rotation 1.17, and in grain-row-crop rotation 1.85 . Without application of fertilizers, the values were 1.40, 1.14 and 1.48, respectively. Against the background of straw ploughed into the soil + mineral fertilizers in crop rotation, this value was 1.45 .

The total content of insoluble residue was the highest in crop rotation at the fertilizer dose of $50 \mathrm{t} / \mathrm{ha}$ manure $+\mathrm{N}_{100} \mathrm{P}_{100} \mathrm{~K}_{100}$, specifically $0.88 \%$, whereas in the row-crop rotation and grain-row crop rotation it was 0.82 and $0.80 \%$.

The nonhydrolyzed residue is a potential source of humus and can be the most fully enhanced against the background of the organomineral fertilization in crop rotation [14]. Consequently, the content of humus in crop rotations is due to the increase in the nonhydrolyzed residue.

The practice of fertilization and crop rotation had an effect on the capability of humic acids of being bound by $\mathrm{Ca}$ and $\mathrm{R}_{2} \mathrm{O}_{3}$. Thus, for the application of the organomineral fertilizer in crop rotation, the content of humic acids fixed by Ca was $82.0 \%$, while in row-crop rotation $85.6 \%$ and in grain-row crop rotation $82.0 \%$, which indicated a tendency to decrease compared with the control treatment without fertilizers due to deterioration of physical and chemical characteristics of the soil.

The content of mobile organic matter (labile humus) the most fully characterizes the effective fertility of the soil [2]. The content of labile humus for the organomineral fertilization was $0.270,0.256$ and 0.254 , while without fertilization $0.294,0.183$ and $0.198 \%$; when ploughing straw into the soil and introducing mineral fertilizers, the content of labile humus was $0.259 \%$.

Consequently, the content of labile humus of typical leached chernozem increases with the introduction of fertilizers. At the same time, the content of fixed by $\mathrm{R}_{2} \mathrm{O}_{3}$ acids in all the treatments against the background of fertilization had an advantage compared with the unfertilized background and ranged from 14.4 to $18.0 \%$. 
Table 1. Group composition of humus in the topsoil of typical leached chernozem as affected by fertilization program

and crop rotation (Bila Tserkva RBS, 2014)

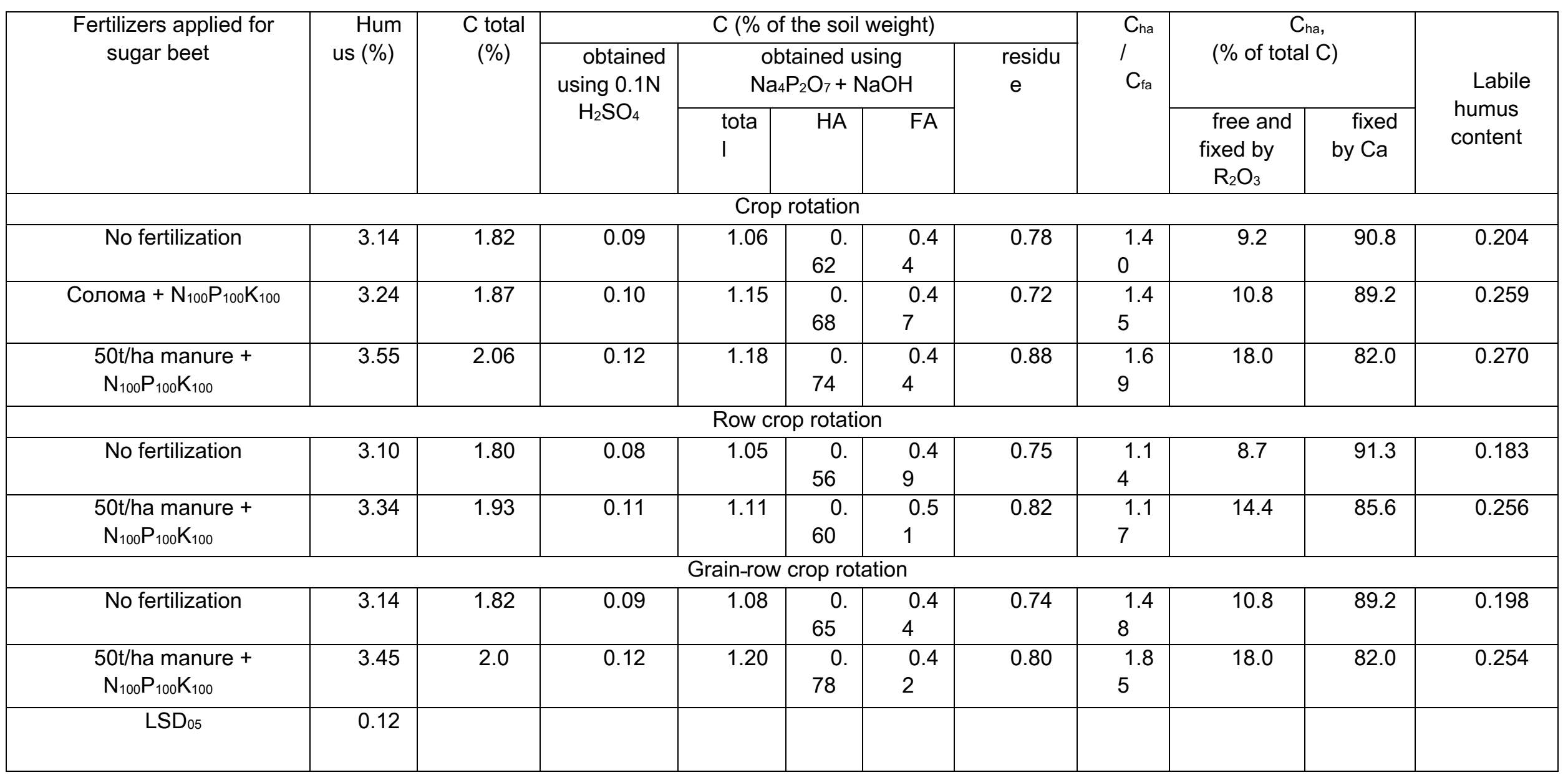




\section{Conclusions}

In the treatment with application of $50 \mathrm{t} /$ ha manure $+\mathrm{N}_{100} \mathrm{P}_{100} \mathrm{~K}_{100}$ for sugar beet and $8.3 \mathrm{t} /$ ha manure + $\mathrm{N}_{43} \mathrm{P}_{43} \mathrm{~K}_{43}$ per crop rotation, humus content in crop rotation reached $3.55 \%$, in row-crop rotation $3.34 \%$ and in grain - row crop rotation $3.45 \%$. The content of labile humus was $0.270,0.256$ and $0.254 \%$, whereas without fertilizers $0.204,0.183$ and $0.198 \%$, respectively.

When ploughing harvest residues into the soil $+\mathrm{N}_{100} \mathrm{P}_{100} \mathrm{~K}_{100}$, humus content in the topsoil was $3.24 \%$ and the content of its labile form was $0.259 \%$, which was by $0.14 \%$ higher than in the unfertilized treatment of the crop rotation,

Application of the organomineral fertilizers resulted in the content of humic acids in crop rotation of $0.74 \%$, in row crop rotation of $0.60 \%$, whereas in the treatment without fertilizers of 0.62 and $0.56 \%$, respectively.

The correlation between humic and fulvic acids, respectively, for the application of organomineral fertilization program in crop rotation was 1.69, in row crop rotation 1.17, and in grain-row crop rotation $1.85 \%$. Without application of fertilizers, the values were as follows: $1.40,1.14$ and 1.48 , respectively. Against the background of straw ploughed into the soil + mineral fertilizers, in crop rotation the ratio was 1.45 .

\section{Bibliografija}

1. Capko Ju.L., Ivanova V.I., Andrijchenko O.A. Zmina jakisnogo skladu gumusu chornozemu opidzolenogo pravoberezhnogo Lisostepu vplyvy riznyh system dobryv // Agrohimija i g'runtoznavstvo. 1992. - № 54. - S. 12-14

2. Bacula O.O., E.A. Golovachov, O.G. Derevjanenko, T. I. Laktionova Zabezpechenist' bezdeficytnogo balansu gumusu v g'runti. - K.: Urozhaj. - 1987. - $128 \mathrm{~s}$.

3. Bulygin S.Ju Gumusovyj stan chornozemiv Ukrai'ny/ S.Ju. bultgin, V.V. Degtjar'ov, S.V Krohin // Visnyk agrarnoi' nauky. - 2007. - №2. - S. 13-16

4. Degtjar'ov V. V. Gumus chornozemiv Lisostepu i Stepu Ukrai'ny: monografija / V. V. Degtjar'ov $/ / H$.: Majdan, 2011. $-360 \mathrm{~s}$.

5. Nikiforenko P.I., Pered'ko O.I. Procesy gumusoutvorennja i gumusovyj stan g'runtu zalezhno vid systemy udobrennja v sivozmini // Zemlerobstvo. - 1995. - Vyp. 70. - S. 3-11.

6. Shkarednyj I.S., Glushhenko I.V., Kisiljevs'ka M.O., Transformacija gumusu pry riznyh systemah zemlerobstva // Systema zemlerobstva u burjakivnyctvi. - K.: ICB, 1997. - S. 171-185.

7. Orlov D.S. Himija pochv. - M.: MGU, 1985. $-378 \mathrm{~s}$.

8. Ganenko V.P. Gumus pochv Moldavii i ego transformacija pod vlijaniem udobrenij. - Kishinjov: Shtinica, 1991. - S. 128.

9. Bacula O.O. Skryl'nyk Э.V., Kravec' T.F. Vplyv dobryv i roslynnyh reshtok na gumusovyj stan gruntiv // Agrohimija i gruntoznavstvo. - 1998. - № 59. - S. 115-121.

10. Luk'janchykova Z.Y.. Soderzhanye y sostav gumusa v pochvah pry yntensyvnom zemledelyy // Pochvovedenye. - 1980. - № 6. - S.79-90.

11. Shevcova L.K. Gumusnoe sostojanye y azotnыj fon osnovndh typov pochv pry dlytel'nom prymenenyy udobrenyj // Avtoreferat dys. dok. byol. nauk. - M.: 1988. - S. 40.

12. Gamzykov P.P., Kulagyna M.N.. Vlyjanye dlytel'nogo prymenenyja udobrenyj na organycheskoe veshhestvo pochv // Pochvovedenye. - 1986. - № 8. - s. 58-63.

13. Getmanec A.Ja., Dudchenko L.M., Usenja Ju.Y. Vlyjanye dlytel'nogo prymenenyja udobrenyj na agrohymycheskye pokazately obыknovennogo chernozëma y urozhaj zernovыh kul'tur v sevooborote // Agrohymyja. - 1977. - № 10. - S. 51-56.

14. Zagorcha K.L. Optymyzacyja systemы udobrenyja v polevыh sevooborotah. - Kyshenëv: Shynnyca, 1990. - $287 \mathrm{~s}$.

15. Cvej Ja.P., Ivanina V.V., Petrova O.T. Grupovyj ta frakcijnyj sklad gumusu chornozemu typovogo v riznorotacijnyh sivozminah //Visnyk agrarnoi' nauky. . - 2013r. . - № 1. . - S. 17. - 19

16. Spelr T.W., Ross D.J. A comparison of the effect of airdrying and acetone dehydration on soil enzyme activities // Soil Biol, and Biochem. - 1981. - Vol. 13. - P. 225-224.

17. Stanford G., Epstein E. Nitrogen mineralization. Water relations in soils // SoU Sci.Soc. Amer. Proc. - 1974. - 38, N 1. - P. 103-107.

18. Williams M. R., Goh K. M. Changes in the molecular weight distribution of soil organic matter during humificatin // Plant and Soil. - 1982. - 25, N 4. - P, 335-340. 